University of Nebraska - Lincoln

DigitalCommons@University of Nebraska - Lincoln

USDA Wildlife Services - Staff Publications

U.S. Department of Agriculture: Animal and Plant Health Inspection Service

2018

Diverse examples from managing invasive vertebrate species on inhabited islands of the United States

\author{
Richard M. Engeman \\ USDA National Wildlife Research Center, s_r100@yahoo.com \\ Michael L. Avery \\ USDA National Wildlife Research Center \\ Aaron B. Shiels \\ USDA National Wildlife Research Center \\ Are R. Berentsen \\ USDA National Wildlife Research Center \\ Kurt C. VerCauteren \\ USDA National Wildlife Research Center, kurt.c.vercauteren@usda.gov
}

See next page for additional authors

Follow this and additional works at: https://digitalcommons.unl.edu/icwdm_usdanwrc

Part of the Life Sciences Commons

Engeman, Richard M.; Avery, Michael L.; Shiels, Aaron B.; Berentsen, Are R.; VerCauteren, Kurt C.; Sugihara, Robert T.; Duffiney, Anthony G.; Clark, Craig S.; and Eisemann, John D., "Diverse examples from managing invasive vertebrate species on inhabited islands of the United States" (2018). USDA Wildlife Services Staff Publications. 2187.

https://digitalcommons.unl.edu/icwdm_usdanwrc/2187

This Article is brought to you for free and open access by the U.S. Department of Agriculture: Animal and Plant Health Inspection Service at DigitalCommons@University of Nebraska - Lincoln. It has been accepted for inclusion in USDA Wildlife Services - Staff Publications by an authorized administrator of DigitalCommons@University of Nebraska - Lincoln. 


\section{Authors}

Richard M. Engeman, Michael L. Avery, Aaron B. Shiels, Are R. Berentsen, Kurt C. VerCauteren, Robert T. Sugihara, Anthony G. Duffiney, Craig S. Clark, and John D. Eisemann 


\title{
Diverse examples from managing invasive vertebrate species on inhabited islands of the United States
}

\author{
Richard M. Engeman ${ }^{a}$, Michael L. Avery ${ }^{b}$, Aaron B. Shiels $^{a}$, Are R. Berentsen ${ }^{a}$, \\ Kurt C. VerCauteren ${ }^{a}$, Robert T. Sugihara ${ }^{c}$, Anthony G. Duffiney ${ }^{d}$, Craig S. Clark ${ }^{\mathrm{e}}$ and \\ John D. Eisemann ${ }^{a}$
}

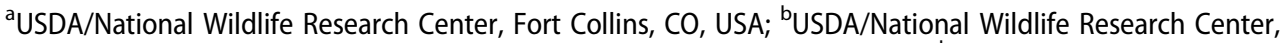

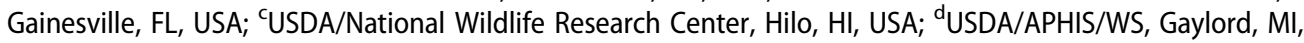
USA; ${ }^{\mathrm{U} U S D A}$ /APHIS/WS, Honolulu, HI, USA

\begin{abstract}
A wide array of sizes, ecosystems, cultures, and invasive wildlife are represented among inhabited islands. Here, six cases from the United States of America (US) are selected to illustrate the high diversity of invasive animal management issues and objectives. We outline the background, define the problems and management objectives. We identify the management approaches and discuss the results and influences as they specifically relate to inhabited islands. The examples are: (1) Gambian giant pouched rats on Grassy Key, Florida; (2) coqui frogs on Kaua'i, Hawai'i; (3) feral swine on Cayo Costa Island, Florida; (4) rodents and monitor lizards on Cocos Island, Guam; (5) black spiny-tailed iguanas (ctenosaurs) on Gasparilla Island, Florida; and (6) mongooses on Puerto Rico. The outcomes of the programs are discussed, particularly in relation to the impact of human habitation on success.
\end{abstract}

\section{KEYWORDS}

Control; eradication; integrated pest management; management objectives

\section{Introduction}

The United States of America (US) has responsibility for islands ranging from barrier islands along mainland coasts, to islands in the Caribbean, the middle and western edge of the Pacific Ocean, and the Arctic Ocean. Both inhabited and uninhabited islands are homes to invasive vertebrate species. Besides the breadth of geographical locations, island size varies greatly from oceanic rocks to Hawai'i's Big Island at $10,433 \mathrm{~km}^{2}$. The habitats and terrains found on islands vary wildly, often within the same island. On the Big Island of Hawai'I, the altitude is from sea level to $>4200 \mathrm{~m}$, average annual rainfall ranges from $467 \mathrm{~mm} /$ year at Kailua Kona to $3219 \mathrm{~mm} /$ year at Hilo (Giambelluca et al. 2013), and ecosystems vary from tropical rainforest, to desert, to alpine. Similarly, island human population densities, compositions, and cultures are heterogeneous. We use six islands to illustrate the varying circumstances, objectives, and approaches for invasive species management on inhabited US islands. Our disparate examples demonstrate 
diversity in vertebrate species, island types, and management approaches. For consistency, we apply a structure for describing the management situations:

- background and problem description,

- management objective,

- management approach, and

- result, including influences from being inhabited.

This framework enables a ready assessment of specific invasive species problems on each island and associated management contexts.

\section{Case 1: Gambian giant pouched rats on Grassy Key, Florida}

\section{Background and problem}

Around 1999, eight Gambian giant pouched rats (Cricetomys gamnianus) escaped from a pet breeder on Grassy Key, a $\sim 400$ ha island halfway down the island chain (keys) extending from Florida's southern tip (Perry et al. 2006). Grassy Key is almost entirely privately owned, with nearly 500 properties. In 2007, a resident alerted authorities about C. gamnianus presence after media reports associated them with a monkeypox outbreak; a virus related to, but milder than smallpox (Centers for Disease Control 2003). Without this notification, the population may have had opportunity to disperse to mainland Florida before action was taken.

C. gamnianus, native to Africa, could potentially become a highly destructive invasive species in the US. It is among the largest rat species, with males weighing up to $2.8 \mathrm{~kg}$ (Rosevear 1969). They are omnivorous, consuming vegetables, fruits, and invertebrates (Ajayi 1975; Fiedler 1994; Smithers 1983). C. gamnianus are highly fecund, with 4-5 litters/year of 1-5 offspring (Ajayi 1975; Hayssen et al. 1993; Rosevear 1969). Besides monkeypox, this genus has been linked to other potentially pathogenic zoonoses transmittable to humans. Its large size, high fecundity, omnivorous diet, wide native range, and potential as disease vector made C. gamnianus an immediate invasive threat in the Florida Keys and beyond.

\section{Management objective}

Severe threats posed to natural ecosystems, agriculture, and human health prompted an eradication effort. However, acknowledging the significant threats to human interests from invasive species does not ensure an eradication effort will occur, or succeed (e.g. Engeman et al. 2007b), especially for novel species in new environments. The eradication effort required development of information and methods on species' distribution, effective control technologies, and the political will at state and federal levels (including funding) to proceed.

\section{Management approach}

Obtaining key information, developing techniques and tools, and implementing the eradication involved six phases: 
1. verify presence and distribution,

2. develop detection and population monitoring methods,

3. develop and test potential control tools,

4. test eradication approach,

5. apply methods to primary population, and

6. surveillance (survivors, satellite populations).

First, a breeding population was confirmed (Perry et al. 2006). Subsequent ecological modelling indicated C. gamnianus could invade and establish throughout the US Gulf Coast, and beyond to Central America (Peterson et. al. 2006). Wider areas of North America were also potentially vulnerable.

The second phase involved developing means to rapidly detect C. gamnianus, followed by monitoring their distribution and relative abundance. Methods included live trapping, trail cameras, and tracking tiles. Cameras and tracking tiles also detected large numbers of non-targets. Simultaneous monitoring of non-target species provided information for reducing hazards to non-target species from C. gamnianus control methods, and for reducing non-target interference with control technologies. Cameras and tracking tiles also produced data for population indexing (Engeman 2005). Tracking tiles recorded tracks using minimal resources, but were more labour-intensive than trail cameras, and were applied where risk of theft or vandalism precluded camera deployment. Cameras recorded large numbers of C. gamnianus visits without being hindered by non-target species saturation. Camera data reliably evaluated control efficacy, detected geographically varying C. gamnianus abundances, and optimised control device deployment (Engeman et al. 2007b). Camera surveys verified C. gamnianus survival on Grassy Key after it was over-washed by Hurricane Wilma's storm surge.

Trapping enabled investigators to: (1) detect C. gamnianus presence, (2) refine distribution information, (3) refine trapping techniques, and (4) evaluate non-target species influences on trapping. Cage traps readily captured C. gamnianus. However, non-target trap saturation impaired C. gamnianus trapping efficiency (Engeman et al. 2007b), as $\sim 5.5$ times more non-target animals were captured, mostly raccoons (Procyon lotor), but also Virginia opossums (Didelphis virginiana), black rats (Rattus rattus), and feral cats (Felis catus).

Multiple detection and survey methods identified C. gamnianus distribution on Grassy Key and whether they were on nearby islands. Soil-filled causeways connect Grassy Key to its western neighbours (originally separated by saltwater), while an 11-km bridge connects it to keys to the east. Surveys focused on keys nearby Grassy Key and those involved in transfer of trash and hurricane debris from Grassy Key (Engeman et al. 2007b).

Outside Grassy Key, C. gamnianus were found only on Crawl Key, 220 m west of Grassy Key, demonstrating dispersal across the short soil-filled causeway (Engeman et al. 2007b). Rockland hammock habitat most suitable for human residential development was preferred by C. gamnianus. Human development greatly enhanced the habitat for C. gamnianus by providing bountiful resources like refuse, pet food, water, and refugia.

The third phase developed control tools for eradication. Bait acceptance and efficacy were rapidly evaluated using captured C. gamnianus. All rats died after consuming a small amount of 2.0 per cent zinc phosphide bait (Engeman et al. 2006b, 2007b). A 


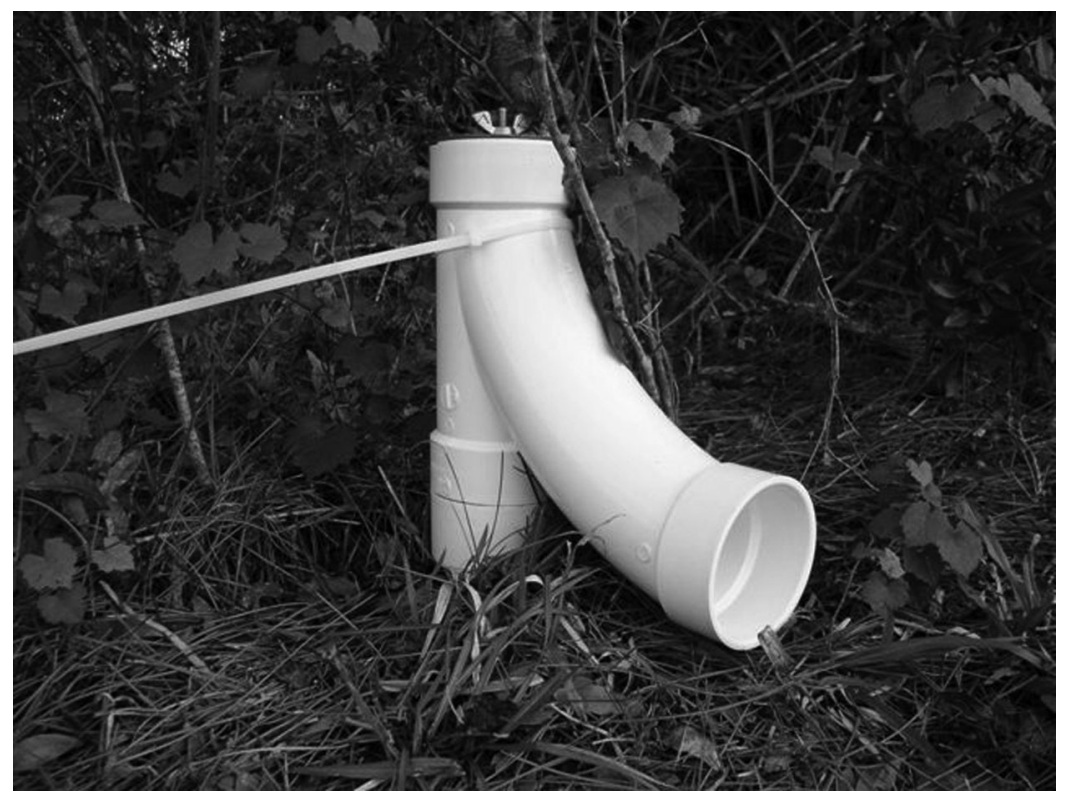

Figure 1. A custom-designed bait station for delivering baits to Gambian giant pouched rats in the Florida Keys while excluding native species. Bait is accessed and placed in the 'heel' of the bootshaped design through the locking lid on top (Photo by J. Woolard).

custom-designed bait station (Figure 1) made of PVC pipe was developed and tested using untreated bait with photographic verification of bait accessibility for C. gamnianus while excluding native species (Engeman et al. 2006b, 2007b). Trapping was required in areas where bait was not permitted by property owners, where C. gamnianus became aversively conditioned to bait by consuming a sub-lethal dose, and for rats not attracted to bait stations. Further refinement and testing improved baits and attractants (Engeman et al. 2007b).

The fourth eradication phase tested and fine-tuned methods in a pilot eradication on Crawl Key (Engeman et al. 2007b). Pre-baiting for three days was done using toxicantfree bait in a $40 \times 40 \mathrm{~m}$ bait station grid across Crawl Key to prevent 'bait-shyness'. Next, toxic bait was applied for seven days. All Crawl Key was baited simultaneously. Afterwards, camera surveys found no C. gamnianus on Crawl Key, although Hurricane Wilma's over-washing storm surge possibly contributed to mortality.

The fifth phase was to eradicate the primary population of C. gamnianus on Grassy Key (Engeman et al. 2007b). In late 2006 and early 2007, bait stations were distributed across Grassy Key. Optimal C. gamnianus habitat had $40 \times 40 \mathrm{~m}$ bait station grids and marginal areas had $50 \times 50 \mathrm{~m}$ grids. Public meeting, mailings, and door-to-door visits were conducted to obtain property owner approvals. A minority of property owners refused entry to their properties or would not allow toxic bait on their properties. Baiting was conducted as close as legally permissible to those properties with trapping anticipated as a necessary addition for eradication.

To reduce non-target species hazards and interference, live-trapping safely removed many native non-target animals to a nearby island. With $\sim 1000$ bait stations, baiting 
was sequentially applied in zones from east to west during May-June 2007. Again, prebaiting with nontoxic bait for three days was followed by seven days of toxic bait application.

Post-baiting camera surveys revealed some C. gamnianus activity, primarily in residential areas with alternative food sources (especially pet food) and where property owners did not permit toxicant use. These areas were intensively trapped using cantaloupe as an alternative attractant. Baiting was again applied in September 2007.

Surveillance, the final phase, is ongoing. Eradication was to be considered successful with no C. gamnianus discovered during two years of intensive surveys. Vigilance and periodic surveys would continue to ensure no remnants of the population went undetected. Unfortunately, since the 2007 eradication effort, C. gamnianus have occasionally been observed and captured on Grassy Key, usually near properties not granting access. Often many months elapsed between sightings. When detected, efforts were made to remove them and will continue until eradication is complete.

\section{The result and influences of being an inhabited island}

The few property owners who did not permit access offered C. gamnianus refuge areas outside of contact with control activities. Thus, one 'obligate rule' for successful eradication was compromised: all target species individuals must be at risk for removal (Parkes \& Murphy 2003). Additionally, 100 cage traps were vandalised, reducing control resources and squandering control time and effort, and C. gamnianus released from these traps may have become trap-shy and difficult to recapture. Some residents maintained feeding stations for feral cats, potentially offering C. gamnianus alternative food sources and reducing chances they would enter a trap or bait station. Persistent surveillance and working with property owners to apply control methods will hopefully result in all remaining C. gamnianus being removed.

\section{Case 2: Coqui frogs on Kaua'i, Hawai'i}

\section{Background and problem}

Coqui frogs (Eleutherodactylus coqui) are small $(<65 \mathrm{~mm}$ SVL), nocturnal tree frogs, native to Puerto Rico (Beard et al. 2008) and introduced to Hawai'i in the late 1980s through horticultural trade (Kraus et al. 1999). Their loud mating call is their most distinctive feature, sometimes exceeding $85 \mathrm{db}$ at $0.5 \mathrm{~m}$ (Beard \& Pitt 2005).

Hawai'i's environment, economy, and human health are negatively impacted by dense frog populations and loud mating calls. Coquis disturb sleep and night-time tranquillity, deterring people from living in coqui areas (Pitt et al. 2012), thereby decreasing property values (Kaiser \& Burnett 2006). People are unwilling to purchase products potentially infested with coquis or their eggs, decreasing plant growers' sales, increasing quarantine procedures, destroying plant shipments, and increasing pest control costs (Beard et al. 2009; Pitt et al. 2012). Coquis may compete with native species or be a food resource for invasive predators (Pitt et al. 2012). Coquis occur in virtually all habitat types from sea level to $1300 \mathrm{~m}$ elevation. Population densities can reach 55,000 frogs/ha in some areas (Kraus \& Campbell 2002; Sin \& Radford 2007). 
Hawai'i's first coqui voucher specimen was collected on Maui in 1997 (Kraus et al. 1999; Kraus \& Campbell 2002). Coquis were first documented on Kaua'i in 1999, with the relatively small population confined to the town of Lawai (Beard et al. 2009). Coqui frog eradication has been considered unattainable on the Island of Hawai' $i$, and unlikely for Maui, but appeared possible on Kaua'i (Kraus et al. 1999; Kraus \& Campbell 2002; Sin \& Radford 2007).

\section{Management objective}

Eradicate the small, geographically confined coqui population from Kaua'i.

\section{Management approach}

Coqui frog populations are most effectively controlled using chemicals applied from backpack sprayers. Three frog toxicants received some level of Environmental Protection Agency (EPA) approval for use at some time. Caffeine was approved for limited use from 2001 to 2002, but never widely used due to human health concerns (Pitt et al. 2012). Since 2002, citric acid, a common food additive, has been used for controlling frog populations with minimal non-target effects (Pitt et al. 2012; Pitt \& Sin 2004). Later, hydrated lime solution was found effective and more economical than citric acid. It was legal from 2005 to 2008, but the product's label was not renewed (Pitt et al. 2012). Only citric acid is currently EPA-approved for controlling coquis in Hawai'i (Pitt et al. 2012).

Management has relied on spraying infested areas, habitat modification, hand capture, hot water treatments, PVC refugia traps, and systematic follow-up (Beard et al. 2009; Sin \& Radford 2007). Initial coqui removal steps on Kaua'i were conducted in 2003 and included: (1) determining distribution, (2) identifying stakeholder and co-operator interests, expertise, and roles, and (3) assessing feasibility and efficacy of citric acid spray. The first eradication attempt on Kaua'i in 2003 was believed successful by some (Leone 2003), but coquis persisted. Throughout 2005, sporadic attempts involving many partners were made to remove coquis, but they continued geographic expansion, threatening to grow beyond feasible eradication and prompting coordination in 2005 among county, state, and federal government entities and private representatives to plan coqui elimination (Gundersen 2012). A top priority was habitat modification by reducing dense foliage $<35 \mathrm{~cm}$ diameter, and spraying both citric acid and hydrated lime solutions (Gundersen 2012). Electronic monitoring for coqui mating calls was developed in 2007 and implemented using recording devices and ornithological software, with $>4000$ ha eventually surveyed (Gundersen 2012). By 2008, coqui populations appeared nearly eradicated (Eagle 2008). By 2009-2010, control became focused only where coqui mating calls were located (Gundersen 2012). In 2012, after 12 consecutive months without detecting calling frogs, Kaua'i was declared 'coqui free' (Division of Forestry \& Wildlife 2012; Gundersen 2012). Nevertheless, at least seven coquis have since been located and captured on Kaua'i, most recently in 2014 at a nursery (D'Angelo 2014; Javier 2014). Whether these frogs recently arrived or survived control, reports on their existence demonstrated the value of vigilance through monitoring and public outreach. 


\section{The result and influences of being an inhabited island}

On Hawai' $i$ and Maui, there was little effort towards eradicating establishing coqui populations, controlling their spread, or studying the problem despite warnings concerning potential impacts (Kraus \& Campbell 2002). The lessons from Hawai'i and Maui showed prompt action would be needed towards incipient populations on other Hawaiian Islands. Persistent effort over nine years with continual development and refinement of control measures essentially extirpated Kaua'i's coqui frog population.

Coqui eradication on Kaua'i faced many challenges, including sufficient resources to carry out the eradication rapidly and effectively. Possibly, with more resources, eradication could have succeeded when first attempted in 2003. Credit goes to Kaua'i county, state, and federal partners outreach to private citizens and volunteers for holding the coqui population in check and ultimately extirpating it. Electronic surveillance and public outreach will continue to be vital for locating new arrivals and making rapid response possible. Citizens are motivated to control coquis on their properties, given safe and reliable tools and application know-how (Kraus \& Campbell 2002).

\section{Case 3: Feral swine on Cayo Costa Island, Florida}

\section{Background and problem}

Cayo Costa Island, a $10 \mathrm{~km}^{2}$ barrier island along Florida's west coast, remains largely unchanged since Spanish explorer Ponce de Leon viewed it 500 years ago. Cayo Costa is accessible only by boat and provides beach nesting habitat for state and federally listed sea turtles and shorebirds. Approximately two dozen residences are on the island.

Swine (Sus scrofa) were introduced as a food resource for resident Cuban fishermen by the 1800s. Subsequent releases followed to the 1980s. Feral swine negatively impacted sea turtle and shorebird nest success, damaged plant communities, dispersed invasive plant species, and damaged irreplaceable archaeological sites (Florida Department of Environmental Protection 2005).

\section{Management objective}

The damages inflicted on Cayo Costa Island prompted targeting swine for eradication (Engeman et al. 2010). Successful swine removal from Cayo Costa Island also required swine removal from Punta Blanca Island, a satellite sand island nearby Cayo Costa Island measuring $2.3 \mathrm{~km}$ long and averaging $0.3 \mathrm{~km}$ wide. Those animals could potentially have repopulated Cayo Costa Island.

\section{Management approach}

A passive tracking methodology for monitoring swine (Engeman et al. 2001, 2007a), damage observations, and other signs comprehensively showed distribution of swine activity and favourable locations for removal activities. After conditioning swine to feeding at bait sites, they were captured in durable, portable pen traps. Swine were also shot over bait and snared on swine trails leading to bait. Swine distribution was reassessed as they were removed (Engeman et al. 2010). 
Punta Blanca Island removal strategies were simplified because those swine were conditioned to being fed by boaters and were removed opportunistically by shooting using a noise-suppressed rifle when they appeared on shore at the boat's arrival, or they were shot over bait (Engeman et al. 2010).

\section{The result and influences of being an inhabited island}

In 2007, 144 swine were removed from Cayo Costa Island with another 22 taken the next year, after which no swine activity was detected (June 2008). Subsequent searches by Florida State Parks staff also found no feral swine sign (July 2008). Some captured swine had been castrated and tagged, indicating human involvement and consequent concerns for future illegal reintroductions. Nine swine were removed from Punta Blanca Island in 2007, with no further sign of activity detected (Engeman et al. 2010).

Combined with concomitant raccoon removal, nest predation rates plunged and nesting success for loggerhead turtles (Caretta caretta) and least terns (Sterna antillarum) improved (Engeman et al. 2010). For example, least tern nests erupted from eight in 2006 to 195 and 208 in 2007 and 2008, with associated production of young (Engeman et al. 2010).

Some Cayo Costa residents disapproved of eradication, and even painted 'Save the pigs!' on a boat bottom to protest (Figure 2). Within weeks after completing eradication in 2008, feral swine reappeared on the island, despite six $\mathrm{km}$ of ocean with treacherous currents between the island and the nearest feral swine population. Thus, an operationally successful eradication can be undermined by a small segment of society. At this writing (2017), another eradication is ongoing, including better relations with residents.

\section{Caes 4: Rodents and mangrove monitor lizards on Cocos Island, Guam}

\section{Background and problem}

Cocos Island is a 34 ha island lying $2.5 \mathrm{~km}$ off southern Guam. Guam had its native terrestrial vertebrate fauna devastated by invasive brown tree snakes (Boiga irregularis) (Engeman \& Vice 2001). However, B. irregularis did not invade Cocos Island. On Guam only four forest bird species evaded extirpation by $B$. irregularis, with two surviving only in captive breeding facilities. Reintroduction attempts for one, the Guam rail or ko'ko' (Gallirallus owstoni), were attempted on Guam in areas depopulated of B. irregularis, but rails were extirpated by feral cats (Felis catus) (US Fish and Wildlife Service 2009). Cocos Island was a potential haven for Guam rail reintroduction due to absence of B. irregularis, feral cats, feral ungulates (Lujan et al. 2010), and potential for removing other possible rail predators.

Cocos Island Resort owns two-thirds of Cocos Island. This day-resort shuttles 50400 tourists daily via boat from Merizo on Guam's southeast coast. Guam Department of Parks and Recreation manages the rest of Cocos Island. Multiple native vertebrate species extirpated on Guam survive on this narrow Island (1.6 km long, 200-300 m wide), making it prime for rail reintroduction. First, populations of exotic predators posing threats to rails or their nests needed removal. Rails are vulnerable to egg predators such as Polynesian rats (Rattus exulans), house mice (Mus musculus) and 


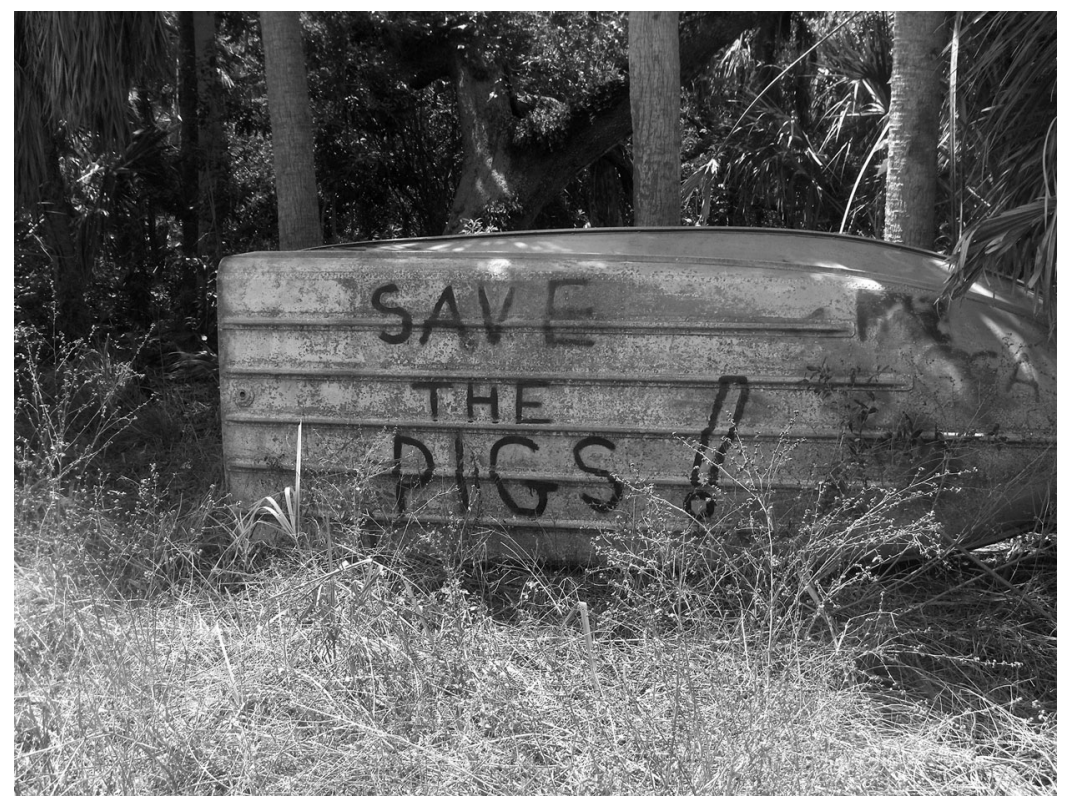

Figure 2. A sign painted on the bottom of a boat propped next a road on Cayo Costa Island to protest the eradication of feral swine (Photo by R. Engeman).

mangrove monitor lizards (Varanus indicus) (US Department of Agriculture 2008; US Fish and Wildlife Service 2009). Monitor lizards also may eat newly released or nesting rails and chicks.

\section{Management objective}

The objective was to provide safe breeding habitat for Guam rails by eradicating Polynesian rats and house mice and suppressing monitor lizards on Cocos Island.

\section{Management approach}

Cocos Island Resort, Guam Department of Agriculture, and the US Fish and Wildlife Service entered an agreement to create safe harbour for Guam rails on Cocos Island (BirdLife International 2015). Guam Department of Agriculture then formed an agreement with US Department of Agriculture's Wildlife Services (US-WS) to eradicate invasive rodents (Lujan et al. 2010) and remove monitor lizards from the island.

Rodenticide bait application was the primary rodent eradication approach. Both Polynesian rats and house mice required eradication while accommodating much smaller home ranges of house mice. To reduce risks to non-target species and increase impact to rodents, eradication operations occurred during the dry season when rodent populations are usually lower, reproductively challenged, and with fewer food resources available. Capture devices (snap, sticky, and live traps) were applied to resort buildings, whereas bait stations were used in $10 \times 10-\mathrm{m}$ grids throughout the landscaped resort grounds. The restaurant and dining room building had the highest trap densities, with 
traps also on rooftops and crossbeams (Lujan et al. 2010). Brodifacoum bait was dispensed from bait stations designed to exclude land crabs. Trapping and bait station deployment began February 2009 and continued until early April. Bait stations were deployed every evening after resort guests left the island. Every morning between 06:00 and 07:30, bait stations were collected and stored before resort staff arrived. Elsewhere on the island, Diphacinone bait was applied in short-duration intermittent 'pulse baiting' to limit non-target species risks (Eason \& Spurr 1995). Two hand-broadcast applications of Diphacinone bait spaced one week apart in March 2009 were made in forested areas from transects (Lujan et al. 2010). Live traps deployed throughout the island were preferred for monitor lizard removal. Live trapped monitor lizards were relocated to mainland Guam by Guam Department of Agriculture. Air rifles were used in forested areas as required.

Following rodent removal, established B. irregularis control methods (Engeman \& Vice 2001) were applied to detect if B. irregularis inhabited Cocos Island. B. irregularis monitoring and biosecurity measures continue to help prevent future introduction.

\section{The result and influences of being an inhabited island}

Management objectives were achieved: rodents have not been seen on Cocos Island since March 2009. Monitor lizard surveys showed low numbers, and no B. irregularis have been detected. The predator free status resulted in releases of Guam rails on Cocos Island beginning in November 2010, and successful breeding has since been observed (BirdLife International 2015).

This success required cooperation among multiple territorial and federal agencies and Cocos Island Resort. Public meetings informed and received input from local citizens concerning the proposed eradication. Resort operations posed challenges, because bait could not be broadcast in areas of human habitation. Standard rodenticide delivery systems (bait stations) could not be used in areas for food preparation and dining. Broadcasted bait pellets on resort grounds would have presented potential human safety risks and been visually unappealing to resort guests. Resort open hours dictated a daily cycle for deployment and removal of bait stations on resort grounds, limiting activity to when the resort was closed. No ferry was available when operations were conducted on the island, requiring operations staff to use personal watercraft for access. Careful planning, coordination, and organisation overcame logistical challenges, producing a successful eradication.

\section{Case 5: Black spiny-tailed iguanas on Gasparilla Island, Florida}

\section{Background and problem}

In 1979, a resident brought three black spiny-tailed iguanas (Ctenosaura similis; Figure 3) from Mexico and released them on Gasparilla Island, an 11-km barrier island off southwestern Florida (Krysko et al. 2003). By the early 2000s, the population of this large lizard native to southern Mexico and Central America had saturated all island habitats, including residential and commercial areas. This species has great reproductive potential with clutches averaging 43 eggs (Fitch \& Henderson 1978). Gasparilla Island is well-developed with residential communities, and $C$. similis thrive in human-altered environments in 
their native range (Fitch \& Henderson 1978). This adaptability, abundant gopher tortoise (Gopherus polyphemus) burrows as refuges, and minimal persecution by humans created conditions for population persistence and expansion.

C. similis eat expensive landscape plantings and invade houses, causing monetary damage and aggravating homeowners. They also threaten sensitive native fauna, and although primarily vegetarian, opportunistically eat other lizards, small birds, rodents, and invertebrates (Fitch \& Hackforth-Jones 1983). Their predatory behaviour potentially jeopardises bird species such as least terns and burrowing owls (Athene cunicularia floridana) (Krysko et al. 2003). They eat the same native plants as gopher tortoises, occupy tortoise burrows (Engeman et al. 2009a; Krysko et al. 2003; McKercher 2001), and prey on juvenile gopher tortoises (Avery et al. 2009). C. similis also eat fruit and disperse seeds of Brazilian pepper (Schinus terebinthifolius) (Florida Department of Environmental Protection 2002; Jackson \& Jackson 2007), which is time consuming and costly to control. C. similis will agonistically attack and kill native snakes (Engeman et al. 2009b). The boundary between Lee and Charlotte counties crosses Gasparilla Island. Residents in each county were sufficiently aggravated that they voted to self-tax to fund iguana population control to reduce their damages.
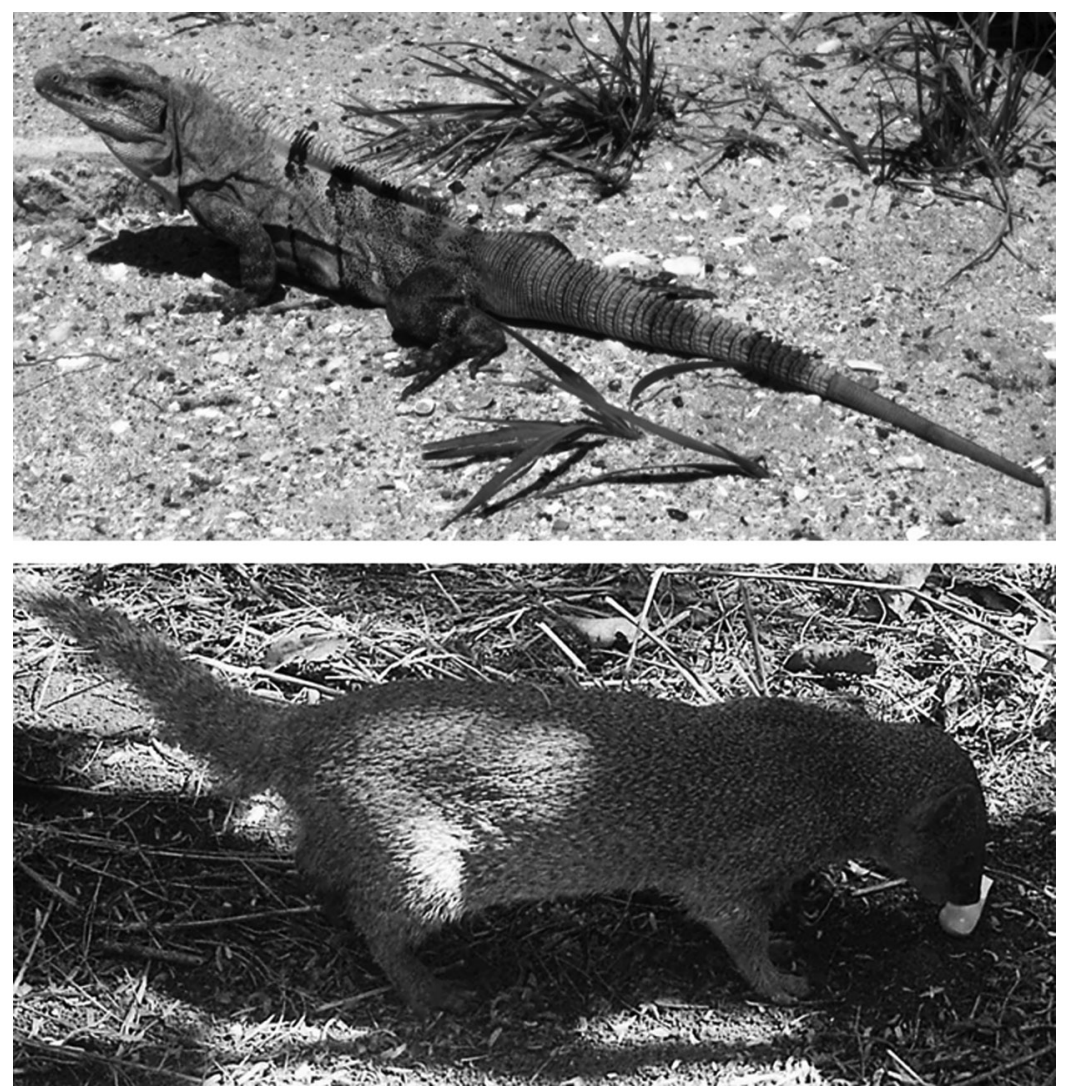

Figure 3. Top - A black spiny-tailed iguana on Gasparilla Island, part of a population that grew from an introduction of three lizards to tens of thousands within 25 years (Photo by R. Engeman). Bottom Mongoose taking an experimental bait being tested for potential to deliver rabies vaccine to mongooses on Puerto Rico (Photo by A. Berentsen). 


\section{Management objective}

The objective was substantial population suppression. Iguana abundance, numerous private properties, oversight by two county governments, and highly varied habitats made eradication a remote possibility, for consideration only after significant population reduction.

\section{Management approach}

The two counties employed different population reduction approaches. In 2007, Lee County paid a private trapper to remove iguanas from the southern portion of Gasparilla Island using a sole-source bounty for each iguana removed. In 2008, Charlotte County on the island's north formed an agreement to remove C. similis with US-WS. In 2009 and 2010, both counties used US-WS personnel for removal. In 2011, Lee County reverted to private trapper services, and Charlotte County retained US-WS.

Iguanas were removed by various trapping strategies and shooting. Due to habitat mixtures of natural, residential and other developed areas, and associated community restrictions, great versatility was required to strategically integrate and optimise human and material resources for maximising iguana removal. Trapping strategies included placing baited cage traps in shaded areas frequented by iguanas, deploying unbaited live traps in gopher tortoise burrow mouths after iguana entry, and placing unbaited live traps along wall bases or other barriers where iguanas travelled. Iguanas were also shot using .22 calibre or air rifles when prudent and safe. Efficacy was expressed as iguana numbers removed per day, and iguanas captured from Charlotte County were studied to assess control efficacy using physiological parameters and population demographics (Avery et al. 2014).

\section{The result and influences of being an inhabited island}

C. similis on Gasparilla Island were nearly free of significant predation pressure prior to control efforts. During 2008-2011, >15,000 iguanas were removed. Daily captures declined from 32/day in 2008 to 1.9 /day in 2011, despite no easing of control effort. Large numbers of hatchlings and sub-adult iguanas in 2008 and 2009 attested to population health when management was initiated. After four years of persistent control, all size classes of $C$. similis were greatly reduced, demonstrating that an otherwise unchecked invasive reptile population with high reproductive capacity can be successfully reduced (Avery et al. 2014). Relaxation of control could allow quick population recovery.

Gasparilla Island C. similis growth rates were less than in their native Nicaragua (Avery et al. 2014; Fitch \& Henderson 1977). Gasparilla Island conditions appear suboptimal for growth and dramatically reduced populations through control implies sustained population suppression might eventually make eradication a consideration.

Iguanas were believed to negatively impact gopher tortoises (Engeman et al. 2011), and iguana depletion was expected to produce increases in hatchling and juvenile tortoises. Anecdotal reports by island residents support this expectation. Many stated juvenile tortoises were not sighted for a number of years before initiation of control, but now they are.

Management of the C. similis population on Gasparilla Island is noteworthy, not only because of iguana ubiquity, density, and damage prompting control, but because this 
might be the only example of an exotic lizard species whose control was initiated by affected residents willing to self-tax to fund control.

\section{Case 6: Small Indian mongooses on Puerto Rico}

\section{Background and problem}

The small Indian mongoose (Herpestes auropunctatus) was introduced to Puerto Rico in the late $1800 \mathrm{~s}$, primarily to control introduced rat (Rattus rattus) damage to sugar cane (Espeut 1882). The strategy failed, because rats are nocturnal, whereas mongooses are diurnal. Mongooses are now pests throughout Puerto Rico. Besides impacts on native fauna (Pimentel 1955), especially endangered Puerto Rican parrots (Amazona vittata; Engeman et al. 2006a), mongooses are a primary rabies reservoir in Puerto Rico (Everard \& Everard 1988, 1992).

The first confirmed case of rabies in mongooses in Puerto Rico was in 1950 (Tierkel et al. 1952). Suspect mongooses tested from 1986 to 1990 revealed 71 per cent exposure to rabies virus, although prevalence of active infection was 2.6 per cent (Everard \& Everard 1992). Velez (1998) found 19.3 per cent of mongooses positive for rabies exposure, and Berentsen et al. (2015) found prevalence up to 40 per cent in some regions.

In 2013, 54 cases of terrestrial rabies were reported in Puerto Rico, with 70 per cent in mongooses and 26 per cent in domestic dogs (Dyer et al. 2014). In 2003, a man bitten by a rabid dog, reportedly bitten by a mongoose, was the last known human rabies fatality (Irizarry-Pasaarell 2011). Puerto Rico human population density is $\sim 400 / \mathrm{km}^{2}$. Large numbers of loosely kept domestic animals and high mongoose population densities make risk for rabies transmission high.

\section{Management objective}

Conduct foundational research to initiate rabies management in mongooses through large-scale distribution of oral rabies vaccine baits.

\section{Management approach}

No mongoose management program exists on Puerto Rico, but limited removal is performed to protect endangered Puerto Rican parrot populations (Quinn et al. 2006). For rabies in mongooses, management tools are being developed to support anticipated management actions modelled after continental US rabies vaccination programs using oral baits (Slate et al. 2009). No wildlife vaccination program exists in Puerto Rico and domestic animal vaccination is not compulsory (Blanton et al. 2010).

Experimental vaccines have performed well for mongooses (Blanton et al. 2006; Vos et al. 2013), but none are commercially available. Mongoose-specific bait matrices for vaccine delivery are being studied to facilitate eventual implementation of vaccination through baiting. Recent trials showed cheese-flavoured baits were preferred over fish and coconut flavours (Berentsen et al. 2014). Additional trials indicated mongooses investigate egg-flavoured baits (Figure 3) more frequently than non-flavoured baits (A. Berentsen, unpublished data). 
Oral rabies vaccination strategies require knowledge of target species population density (Slate et al. 2008), which varies by habitat and season (Guzman-Colon \& Roloff 2015; Johnson et al. 2016; Quinn \& Whisson 2005), and may be higher in areas with anthropogenic resources (Quinn \& Whisson 2005). Increased potential for human-mongoose and domestic animal-mongoose interactions in high population density areas underscore the need for mongoose management and vaccination programs.

\section{The result and influences of being an inhabited island}

Island inhabitants influenced all aspects of rabies in mongooses on Puerto Rico. Initially, island residents imported mongooses for (futile) biocontrol of rats in agriculture. Later, a rabid dog brought to the island released the disease into the mongoose population. Lack of rabies vaccination regulations for pets contributed to the host reservoir of rabies. High human population density and mongooses thriving in areas with anthropogenic resources produced encounters between the public, their animals, and rabid mongooses. For example, picnic grounds in Caribbean National Forest ('El Yunque') are popular public recreation areas. Mongooses there are attracted to food scraps at picnic sites, leading to rabid mongoose attacks on people and elevating public awareness and calls for action.

\section{Discussion}

We selected diverse examples of invasive vertebrate taxa and associated challenges for management or eradication on inhabited US islands. These case studies demonstrate variety in size, habitats, locations, human population densities, demographics, and land ownership. The combinations of invasive species management issues and island scenarios represent only a fraction of possible scenarios for illustrating the diversity of invasive species management issues on inhabited US islands, and influences of inhabitants on management efforts.

Humans, either intentionally or accidentally, are responsible for invasive vertebrate introductions (Cox 1999; Fall et al. 2011). On US islands, reflecting the world in general, invasive vertebrates can be destructive to human interests and quality of life. They can negatively affect human activities, directly harm native species, destroy native habitats and breeding sites, significantly contribute to extinctions and threats to rare species, and diseases and parasites carried by invasive species heighten their impacts on humans, domestic animals, wildlife, and the environment (Fall et al. 2011).

Islands tend to be more vulnerable to, and suffer more severe consequences from invasion by exotic species than continental areas. Isolation, endemism, fewer and smaller populations, and unfilled ecological niches are among the reasons insular species are particularly susceptible to harm by alien species that may find few competitors and predators in their new environment (e.g. Reaser et al. 2007; Tershy et al. 2015). In contrast, the geographic confinement of islands also increases the feasibility of removing invasive species.

Invasive species are often novel for management in their introduced range. Management action often must be preceded by development of methods and strategies, a scenario well-exemplified by developing methods and strategies for eradicating C. gamnianus from Grassy Key (Case 1) and coqui frogs from Kaua'i (Case 2). 
Orally vaccinating mongooses against rabies is novel, and first requires development and testing of baits for acceptance (Case 6).

Human attitudes (by residents, landowners, government staff) can benefit invasive species management efforts, and cause unexpected problems for their management. Community buy-in contributes greatly to success, and is more likely when human values are impacted. Identifying and revealing invasive species impacts on human values can leverage preservation of biodiversity values. Public cooperation and universal land access are crucial for invasive species management, especially eradications. Conversely, public opposition can impede management success. The cases presented show a wide range of support from enthusiastic public buy-in to overt opposition. It is difficult to conceive of greater public buy-in than on Gasparilla Island where citizens in two counties each voted to self-tax to fund iguana removal (Case 5). Likewise, the eradication of rats and mice on Cocos Island would have been impossible without cooperation by the island's resort (Case 4). Conversely, an apparently successful eradication of feral swine on Cayo Costa Island appeared undermined by an opposed public (Case 3), while lack of cooperation by a small minority of property owners has hindered C. gamnianus eradication efforts on Grassy Key (Case 1).

Invasive species often are not recognised as potentially injurious until they become well-established and problems emerge. Even then, some invasive species are defended by individuals or groups. For example, charismatic species can generate public sympathy regardless of damages (e.g. fervent opposition to feral cat management, despite their global destructive infamy on islands [e.g. Nogales et al. 2004, 2013]). While feral swine typically are not considered charismatic, their persistence in the landscape is valued by recreational hunters, which perhaps accounts for opposition to their eradication and subsequent (illegal) reintroduction on Cayo Costa Island (Case 3).

Eradication is most feasible on small geographical scales and for founder populations (Fall et al. 2011), generally making islands more achievable for eradications than continental areas. Rapid response, persistent effort, and surveillance help insure eradication success, but can pose ecological, economic, and political challenges. Newly identified and geographically limited invasive populations on Grassy Key (Case 1) and Kaua'i (Case 2) required substantial effort across years and long-term follow-up surveillance. Delaying management actions increases eradication complexity, expense, and maintenance difficulty (e.g. Fall et al. 2011). Five of the six presented examples had at least considered eradication (Cases 1-5). Invasive species eradication was the stated objective in four of those five (Cases 1-4), with the exception being C. similis on Gasparilla Island (Case 5). Many factors play into deciding whether to eradicate, including but not restricted to: ubiquity and density of the invasive species, island size, difficulty of terrain and habitats where the species is found, observable damage magnitudes and human conflicts, distribution and density of human population, species behavioural characteristics ('Achilles heel' exploitable weakness), availability, expense, and ease of use of removal methods and strategies, and attitudes towards the species (e.g. Fall et al. 2011).

As an invasive population is suppressed, cost per individual removed typically rises in terms of fiscal, material, and time resources. Also, damage rates usually decrease and people's attitudes soften. If population suppression is the primary objective and eradication is not achieved, increased control costs, reduced damage, plus senses of satisfaction by island inhabitants and agencies responsible for action could result in invasive species 
population recovery (e.g. Fall et al. 2011). Monitoring and continued control would be needed.

The six cases illustrate the widely varying contexts for managing invasive species on US islands. Although the settings and circumstances are disparate, a common thread has been the shaping of management outcomes by the people involved, for better or worse.

\section{Disclosure statement}

No potential conflict of interest was reported by the authors.

\section{References}

Avery, ML, Tillman, EA \& Krysko, KL 2009, 'Gopherus polyphemus (gopher tortoise), Ctenosaura similis (Gray's spiny-tailed iguana) predation', Herpetological Review, vol. 40, p. 435.

Avery, ML, Tillman, EA, Spurfeld, C, Engeman, RM, Maciejewski, KP, Brown, JD \& Fetzer, EA 2014, 'Invasive black spiny-tailed iguanas (Ctenosaurus similis) on Gasparilla Island, Florida, USA', Integrative Zoology, vol. 9, pp. 590-597.

Ajayi, SS 1975, 'Observations on the biology, domestication, and reproductive performance of the African giant pouched rat Cricetomys gambianus (Waterhouse) in Nigeria', Mammalia, vol. 39, pp. 344-364.

Beard, KH, Al-Chokhachy, R, Tuttle, NC \& O’Neill, EM 2008, 'Population density and growth rates of Eleutherodactylus coqui in Hawaii', Journal of Herpetology, vol. 42, pp. 626-636.

Beard, KH \& Pitt, WC 2005, 'Potential consequences of the coqui frog invasion in Hawai'i', Diversity and Distributions, vol. 11, pp. 427-433.

Beard, KH, Price, EA \& Pitt, WC 2009, 'Biology and impacts of Pacific Island invasive species: Eleutherodactylus coqui, the Coqui frog (Anura: Leptodactylidae)', Pacific Science, vol. 63, pp. 297-316.

Berentsen, AR, Johnson, SR, Gilbert, AT \& VerCauteren, KC 2015, 'Exposure to rabies in small Indian mongooses (Herpestes auropunctatus) from two regions in Puerto Rico', Journal of Wildlife Diseases, vol. 51, pp. 896-900.

Berentsen, AR, Johnson, SR \& VerCauteren, KC 2014, 'Bait matrix flavor preference by mongoose (Herpestes auropunctatus) in Puerto Rico: implications for oral rabies vaccination', Caribbean Journal of Science, vol. 48, pp. 52-58.

BirdLife International 2015, 'Species factsheet: Hypotaenidia owstoni', viewed January $2015<\mathrm{http}: / /$ www.birdlife.org on>

Blanton, JD, Meadows, A, Murphy, SM, Manangan, J, Hanlon, CA, Faber, M-L, Dietzschold, B \& Rupprecht, CE 2006, 'Vaccination of small Asian mongoose (Herpestes javanicus) against rabies', Journal of Wildlife Diseases, vol. 42, pp. 663-666.

Blanton, JD, Palmer, D \& Rupprecht, CE 2010, 'Rabies surveillance in the United States during 2009', Journal of the American Veterinary Medical Association, vol. 237, pp. 646-657.

Centers for Disease Control 2003, 'Multistate outbreak of monkeypox - Illinois, Indiana, Kansas, Missouri, Ohio, and Wisconsin, 2003', Morbidity and Mortality Weekly Report, vol. 52, pp. 642-644.

Cox, GW 1999, Alien species in North America and Hawaii, Island Press, Washington, DC.

D’Angelo, C 2014, 'KISC combating coqui on Kauai', The Garden Island. May 4, 2014.

Division of Forestry and Wildlife 2012, Report to the twenty-seventh legislature regular session of 2013 budgetary and other issues regarding invasive species, State of Hawaii, Honolulu.

Dyer, JL, Yager, P, Orciari, L, Greenberg, L, Wallace, R, Hanlon, CA \& Blanton, JD 2014, 'Rabies surveillance in the United States during 2013', Journal of the American Veterinary Medical Association, vol. 245, pp. 1111-1123.

Eagle, N 2008, 'Coqui frogs nearly eradicated', The Garden Island, July 4, 2008. 
Eason, CT \& Spurr, EB 1995, 'Review of the toxicity and impacts of brodifacoum on non-target wildlife in New Zealand', New Zealand Journal of Zoology, vol. 22, pp. 371-379.

Engeman, RM 2005, 'Indexing principles and a widely applicable paradigm for indexing animal populations', Wildlife Research, vol. 32, pp. 203-210.

Engeman, RM, Constantin, B, Nelson, M, Woolard, J. \& Bourassa, J 2001, 'Monitoring changes in feral swine abundance and spatial distribution', Environmental Conservation, vol. 28, pp. 235-240.

Engeman, RM, Constantin, B, Shwiff, SA, Smith, HT \& Woolard, J 2007a, 'Adaptive and economic management methods for feral swine control in Florida', Human-Wildlife Conflicts, vol. 1, pp. 178-185.

Engeman, RM, Duffiney, A, Braem, S, Olsen, C, Constantin, BU, Small, P, Dunlap, J \& Griffin, JC 2010, 'Dramatic and immediate improvements in insular nesting success for threatened sea turtles and shorebirds following predator management', Journal of Experimental Marine Biology and Ecology, vol. 395, pp. 147-152.

Engeman, RM, Jacobson, E, Avery, ML \& Meshaka, WE Jr 2011, 'The aggressive invasion of exotic reptiles in Florida with a focus on prominent species: a review', Current Zoology, vol. 57, pp. 599-612.

Engeman, RM, Kennedy, M, Constantin, BU, Christie, ML \& Hall, PT 2009a, 'Ctenosaura similis (black spinytail iguana), Gopherus polyphemus (gopher tortoise) concurrent burrow use', Herpetological Review, vol. 40, p. 84.

Engeman, RM, Kennedy, M, Constantin, BU, Christie, ML \& Hall, PT, 2009b, 'Ctenosaura similis (black spinytail iguana), Coluber constrictor priapus (southern black racer) nonpredatory killing', Herpetological Review, vol. 40, pp. 84-85.

Engeman, RM \& Vice, DS 2001, 'Objectives and integrated approaches for the control of brown treesnakes', Integrated Pest Management Reviews, vol. 6, pp. 59-76.

Engeman, RM, Whisson, D, Quinn, J, Cano, F, Quiñones, P \& White, TH Jr 2006a, 'Monitoring invasive mammalian predator populations sharing habitat with the critically endangered Puerto Rican parrot Amazona vittata', Oryx, vol. 40, pp. 95-102.

Engeman, RM, Witmer, G, Bourassa, JB, Woolard, JW, Constantin, BU, Hall, PT, Hardin, S \& Perry, ND 2007b, The path to eradication of the Gambian giant pouched rat in Florida, in Managing vertebrate invasive species: proceedings of an international symposium, USDA/ APHIS/WS, National Wildlife Research Center, Fort Collins, CO. vol. conference paper, pp. 305-311.

Engeman, RM, Woolard, JW, Perry, ND, Witmer, G, Hardin, S, Brashears, L, Smith, HT, Muiznieks, B \& Constantin, BU 2006b, 'Rapid assessment for a new invasive species threat: the case of the Gambian giant pouched rat in Florida', Wildlife Research, vol. 33, pp. 439-448.

Espeut, WB 1882, 'On the acclimatization of the Indian Mungoos [sic] in Jamaica', Review of Infectious Diseases, vol. 1882, pp. 712-714.

Everard, CO \& Everard, JD 1988, 'Mongoose rabies', Clinical Infectious Diseases, vol. 10, pp. S610-S614.

Everard, CO \& Everard, JD 1992, 'Mongoose rabies in the Caribbean', Annals of the New York Academy of Sciences, vol. 653, pp. 356-366.

Fall, MW, Avery, ML, Campbell, TA, Egan, PJ, Engeman, RM, Pimentel, D, Pitt, WC, Shwiff, SA \& Witmer, GW 2011, 'Rodents and other vertebrate invaders in the United States', in D Pimentel (ed.), Biological invasions: economic and environmental costs of alien plant, animal, and microbe species, 2nd Edition, CRC Press, Boca Raton, FL, pp. 381-410.

Fiedler, L 1994, 'Rodent pest management in eastern Africa', FAO Plant Production and Protection Paper 123. FAO, Rome.

Fitch, HS \& Hackforth-Jones, J 1983, 'Ctenosaura similis (garrobo, iguana negra, ctenosaur)', in Janzen (ed.), Costa Rican natural history, University of Chicago Press, Chicago, pp. 393-396.

Fitch, HS \& Henderson, RW 1977, 'Age and sex differences in the Ctenosaur (Ctenosaura similis)', Milwaukee Public Museum Contributions to Biology and Geology, vol. 11, pp. 1-11.

Fitch, HS \& Henderson, RW 1978, 'Ecology and exploitation of Ctenosaura similis', University of Kansas Science Bulletin, vol. 51, pp. 483-500. 
Florida Department of Environmental Protection 2002, Gasparilla Island State Park Management Plan, Florida Department of Environmental Protection, Florida Park Service, Tallahassee.

Florida Department of Environmental Protection 2005, Cayo Costa State Park Management Plan, Florida Department of Environmental Protection, Florida Park Service, Tallahassee.

Giambelluca, TW, Chen, Q, Frazier, AG, Price, JP, Chen, Y-L, Chu, P-S, Eischeid, JK \& Delparte, DM 2013, 'Online rainfall atlas of Hawai'i', Bulletin of the American Meteorological Society, vol. 94, pp. 313-316. doi:10.1175/BAMS-D-11-00228.1.

Gundersen, K 2012, 'Kaua'i officially coqui-free!', Kia'i Moku, vol. 5, 1, pp. 6-7.

Guzman-Colon, D \& Roloff, GJ 2015, 'Small Indian mongoose (Herpestes auropunctatus) population abundance and effects of habitat features on trapping success in protected areas of eastern Puerto Rico', Caribbean Naturalist, vol. 19, pp. 1-12.

Hayssen, V, Van Tienhoven, A \& Van Tienhoven, A 1993, Asdell's patterns of mammalian reproduction: a compendium of species specific data, Comstock/Cornell University Press, Ithaca, NY.

Irizarry-Pasaarell, EL 2011, 'Rabies situation in Puerto Rico', Inception meeting of the CaribVet Veterinary Public Health Working Group, 12-14 December, San Juan, Puerto Rico.

Jackson, JA \& Jackson, BJS 2007, 'An apparent mutualistic association between invasive exotics: Brazilian pepper (Schinus terebinthifolius) and black spiny-tailed iguanas (Ctenosaura similis)', Natural Areas Journal, vol. 27, pp. 254-257.

Javier, C 2014, 'Coqui Update', Kia'i Moku, vol. 7, p. 3.

Johnson, SR., Berentsen, AR, Ellis, C, Davis, A \& VerCauteren, KC. 2016, 'Application of a raccoon density index to estimate small Indian mongoose densities in Puerto Rico: implications for rabies management', Journal of Wildlife Management, vol. 80, pp. 37-47.

Kaiser, B \& Burnett, K 2006, 'Economic impacts of E. coqui frogs in Hawaii', Interdisciplinary Environmental Review, vol. 8, pp. 1-11.

Kraus, F \& Campbell, EW 2002, 'Human-mediated escalation of a formerly eradicable problem: the invasion of Caribbean frogs in the Hawaiian Islands', Biological Invasions, vol. 4, pp. 327-332.

Kraus, F, Campbell, EW, Allison, A \& Pratt, T 1999, 'Eleutherodactylus frog introductions to Hawai'i', Herpetological Review, vol. 30, pp. 21-25.

Krysko, KL, King, FW, Enge, KM \& Reppas, AT 2003, 'Distribution of the introduced black spinytailed iguana (Ctenosaura similis) on the southwestern coast of Florida', Florida Scientist, vol. 66, pp. 74-79.

Leone, D 2003, 'Citric acid aids fight against Coqui frog', Honolulu Star-Bulletin, June 24.

Lujan, DT, Vice, DS, Guerrero, JP \& Candaso, CC 2010, 'Rodent eradication on Cocos Island, Guam: integrating wildlife damage management, resort operations, and non-target concerns', Proceedings of the Vertebrate Pest Conference, vol. 24, pp. 9-13.

McKercher, E 2001, 'Ctenosaura pectinata (Iguanidae) on Gasparilla Island, Florida: colonization, habitat use, and interactions with Gopherus polyphemus', MS Thesis, University of Florida, Gainesville, FL.

Nogales, M, Martin, A, Tershy, BR, Donlan, CJ, Veitch, D, Puerta, N, Wood, B \& Alonso, J 2004, 'A review of feral cat eradication on islands', Conservation Biology, vol. 18, pp. 310-319.

Nogales, M, Vidal, E, Medina, FM, Bonnaud, E, Tershy, BR, Campbell, KJ \& Zavaleta, ES 2013, 'Feral cats and biodiversity conservation: the urgent prioritization of island management', Bioscience, vol. 63, pp. 804-810.

Parkes, J \& Murphy, E 2003, 'Management of introduced mammals in New Zealand', New Zealand Journal of Zoology, vol. 30, pp. 335-359.

Perry, ND, Hanson, B, Hobgood, W, Lopez, RL, Okraska, CR, Karem, K, Damon, IK \& Carroll, DS 2006, 'New invasive species in southern Florida: Gambian rat (Cricetomys gambianus)', Journal of Mammalogy, vol. 87, pp. 262-264.

Peterson, AT, Papes, M, Reynolds, M, Perry, ND, Hanson, B, Regner, YR, Hutson, C, Muizniek, B, Damon, I \& Carrol, DS 2006, 'Native range ecology and invasive potential of Cricetomys rats in North America', Journal of Mammalogy, vol. 87, pp. 427-432.

Pimentel, D 1955, 'Biology of the Indian mongoose in Puerto Rico', Journal of Mammalogy, vol. 36, pp. 62-68. 
Pitt, WC, Beard, KH \& Doratt, RE 2012, 'Management of invasive Coqui frog populations in Hawai'i', Outlooks on Pest Management, August, vol. 23, pp. 166-169.

Pitt, WC \& Sin, H 2004, 'Dermal toxicity of citric acid based pesticides to introduced Eleutherodactylus frogs in Hawai'i', QA-992 Final Report USDA, APHIS, WS, NWRC, Hilo, HI, $11 \mathrm{pp}$.

Quinn, JH \& Whisson, DA 2005, 'The effects of anthropogenic food on the spatial behaviour of small Indian mongooses (Herpestes javanicus) in a subtropical forest', Journal of the Zoological Society of London, vol. 267, pp. 339-350.

Quinn, JH, Whisson, DA \& Cano, F 2006, 'Managing the small Indian mongoose (Herpestes javanicus) in the midst of human recreation: what is the optimal approach?', Proceedings of the Vertebrate Pest Conference, vol. 22, pp. 393-398.

Reaser, JK, Meyerson LA, Cronk, Q, DePoorter, M, Eldrege LG, Green, E, Kairo, M, Latasi, P, Mack, RN, Mauremootoo, J, O'dowd, D, Orapa, W, Sastroutomo, S, Saunders, A, Shine C, Thrainsson, S \& Vaiutu, L 2007, 'Ecological and socioeconomic impacts of invasive alien species in island ecosystems', Environmental Conservation, vol. 34, pp. 98-111.

Rosevear, DR 1969, The rodents of West Africa, British Museum of Natural History, London.

Sin, H \& Radford, A 2007, 'Coqui frog research and management efforts in Hawai'i', in G Witmer, W Pitt \& K Fagerstone (eds.), Managing vertebrate invasive species: proceedings of an international symposium, USDA/APHIS/WS, National Wildlife Research Center, Fort Collins, CO, pp. 157-167.

Slate, D, Algeo, TP, Nelson, KM, Chipman, RB, Donovan, D, Blanton, JD, Niezgoda, M, Rupprecht, CE \& Bethony, JM 2009, 'Oral rabies vaccination in North America: opportunities, complexities, and challenges', PLoS Neglected Tropical Diseases, 3, e549.

Slate, D, Rupprecht, CE, Donovan, D, Badcock, J, Messier, A, Chipman, RB, Mendoza, M \& Nelson, KM 2008, 'Attaining raccoon rabies management goals: history and challenges', Developmentals in Biologicals, vol. 131, pp. 439-447.

Smithers, R 1983, The mammals of the Southern African subregion, University of Pretoria, Pretoria.

Tershy, BR, Shen, K, Newton, KM, Holmes, ND \& Croll, DA 2015, 'The importance of islands for the protection of biological and linguistic diversity', BioScience, vol. 65, pp. 592-597.

Tierkel, ES, Arbona, G, Rivera, A \& De Juan A 1952, 'Mongoose rabies in Puerto Rico', Public Health Reports (1896-1970), vol. 67, p. 274.

U.S. Department of Agriculture 2008, Final environmental assessment predator control on Cocos Island, Guam, U.S. Department of Agriculture/Animal and Plant Health Inspection Service/ Wildlife Services, Barrigada, Guam.

U.S. Fish and Wildlife Service 2009, Ko'ko' or Guam rail (Gallirallus owstoni) 5-year review summary and evaluation, Pacific Islands Fish and Wildlife Office, Honolulu, HI.

Velez, JV 1998, 'Presencia de anticuerpos antirabicos y diagnóstico de la rabia en mangostas (Herpestes auropunctatus) capturadas en El Bosque Nacional del Caribe (El Yunque)', MS Thesis, University of Puerto Rico, San Juan, Puerto Rico, USA.

Vos, A, Kretzchmar, A, Ortmann, S, Lojkic, I, Hagbla, C, Müller, T, Kaiser, C, Hundt, B \& Schuster, P 2013, 'Oral vaccination of captive small Indian mongooses (Herpestes auropunctatus) against rabies', Journal of Wildlife Diseases, vol. 49, pp. 1033-1036. 